\title{
Lettuce (Lactuca sativa L.) Yield and Yield Components as Affected by Mulching at Teda, Central Gondar, Northwest Ethiopia
}

\author{
Tiru Tesfa*, Derajew Asres, Hulushum Woreta
}

College of Agriculture and Rural Transformation, University of Gondar, Ethiopia

\begin{abstract}
Lettuce (Lactuca sativa L.) is one of the most popular salad crops and occupies the largest production area among salad crops in the world. However, production of lettuce can be limited due to lack of improved production techniques. Farmers in northwestern Ethiopia didn't apply mulching for lettuce. A field study was conducted at Teda in 2018 to evaluate the effect of different mulching materials on yield and yield components of lettuce (Lactuca sativa L.) under irrigation. Five mulching materials used as a treatment viz: white plastic, black plastic, teff straw, chickpea straw and control (without mulch). The treatments were laid out in Randomized Complete Block Design (RCBD) with four replications. Application of mulching increased leaf width, leaf number, plant height, biological yield, root volume, dry matter content and plant height. Lettuce plants mulched with black plastic sheet was shown $78.7 \%$ yield increment as compared to no mulch. The study revealed that black plastic is the best mulching material among the organic and inorganic once for the production of lettuce in the study area.
\end{abstract}

Keywords: mulch, straw, plastic, yield, lettuce

\section{Introduction}

Lettuce (Lactuca sativa L.) an annual leafy herb belongs to the family of Astaraceae is one of the most popular salad crops and occupies the largest production area among salad crops in the world. Lettuce is ranked $26^{\text {th }}$ among vegetables and fruits in terms of nutritive value and $4^{\text {th }}$ in terms of consumption. It is the most popular salad crop in the world and because of used crude, its vitamins inter to human body without change .The nutrient content is highest in the darker green, outer leaves (FAO, 2009). It is popular for its delicate, crispy texture and slightly bitter taste with milky juice as fresh condition. It is the most popular amongst the salad vegetable crops (Squire et al., 1987). Lettuce is originated from Southern Europe and Western Asia and its early forms were used in Egypt around $4500 \mathrm{BC}$. The Romans grew types of lettuce resembling the present romaine cultivars as early as the beginning of the Christian era. The crop was also used in China by the $7^{\text {th }}$ century A.D. (Rashid, 1999). It mainly grows in temperate region and in some cases in the tropic and subtropic region of the world. Lettuce largely produced in greenhouse in temperate region (Lindquist, 1960).

Lettuce is rich in vitamin $\mathrm{A}$ and minerals like calcium and iron. It also contains protein, carbohydrate and vitamin $\mathrm{C}$ and in $100 \mathrm{~g}$ of edible portion of lettuce contains $93.4 \mathrm{~g}$ moisture, $2.1 \mathrm{~g}$ protein, $0.3 \mathrm{~g}$ fat, $1.2 \mathrm{~g}$ minerals, $0.5 \mathrm{~g}$ fiber, $2.5 \mathrm{~g}$ carbohydrates, $310 \mathrm{mg}$ calcium, $80 \mathrm{mg}$ phosphorus, $2.6 \mathrm{mg}$ iron, 1650 I.U. vitamin A, $0.09 \mathrm{mg}$ thiamine, $0.13 \mathrm{mg}$ riboflavin and about $10.0 \mathrm{mg}$ vitamin C (Gopalan and Balaraman, 1966).

Lettuce is one of the major vegetable crops produced in Ethiopia. Ethiopia is one of a few market developing countries that have been producing lettuce for local consumption (Geleta, 1998). It is extensively grown in most parts of Ethiopia on diverse ecology. 
Plastic mulches are commonly used in vegetable as well as fruit crops production. In vegetable production, numerous advantages had been reported. One of the advantages is it greatly reduces water evaporation from the soil so it minimizes dryness of the soil and thus reduces the frequency of watering. Another and one of the common reasons for its use is to hold the temperature of the soil significantly above what it would otherwise be. Plastic mulches directly impact the microclimate around the plant by modifying the radiation budget thus decreasing the soil water loss. Mulch color determines its energy-radiating behavior and its influence on the microclimate around a vegetable plant.

Mulching materials have effect on the seedling emergence and growth performance of lettuce by affecting soil temperature, soil structure, soil moisture and weed emergence, these all factors affects the yield and yield components of lettuce including germination percentage (Bosland and Votave, 2000).

Knowing the effect of different mulching material is very important because most of the time producers of lettuce do not consider about effect of mulch. As a result this study was conducted to investigate the effects of different mulching materials on the yield and yield component of lettuce at Teda, Central Gondar, Ethiopia.

\section{Materials and Methods}

\section{Description of the Study Area}

Field experiment was conducted in University of Gondar, College of Agriculture and Rural Transformation in Horticulture demonstration site at Teda during 2018 under irrigation from February to May, 2018. The experimental site is located in the geographical location of between longitude $37^{0}-48^{0} \mathrm{E}$ to $\mathrm{W}$ and latitudes $12^{0}-24^{0} \mathrm{~N}$ to $\mathrm{S}$. The experimental site lies at an altitude of about 2380 m.a.s.l with the mean annual rainfall of $992.5 \mathrm{~mm}$. The area experiences medium unimodal rainfall distribution pattern which extends from June to Mid-September. The soil type is vertisol and characterized with $5.5 \mathrm{pH}$. The average annual maximum and minimum temperature are $28.5^{\circ} \mathrm{C}$ and $13.5^{\circ} \mathrm{C}$, respectively (Melaka et al., 2008).

\section{Experimental Material and Experimental Design}

In this study a lettuce variety "great lake" was used as a test crop. Treatments were teff straw, chickpea straw, white plastic sheet, black plastic sheet and no mulch were laid in Randomized Complete Block Design (RCBD) with four replications. The single plot size was $1.5 \mathrm{~m} * 1.8 \mathrm{~m}$ $\left(2.7 \mathrm{~m}^{2}\right)$ accommodating four rows. In the study, spacing of $25 \mathrm{~cm}$ and $45 \mathrm{~cm}$ was used between plants and rows, respectively. The path between blocks and plots were $0.6 \mathrm{~m}$ and $0.5 \mathrm{~m}$, respectively. Each treatment was randomly assigned to each plot.

\section{Data Collection}

Growth and yield parameters were collected during the field experiment by sampling five randomly selected plants from central rows of each experimental unit. Data on plant height, leaf number, leaf length, leaf width, root volume, dry matter content and marketable yield was recorded.

\section{Statistical Analysis}

The data collected were subjected to analysis of variance (ANOVA) according to the procedures stated by Gomez and Gomez (1984) using Statistical Analysis System (SAS) version 9 software package and least significant difference (LSD) was used to separate means at 0.05 probability levels of significance.

\section{Results and Discussion}

\section{Leaf length}

The analysis of variance showed that there was significant difference $(\mathrm{P}<0.01)$ among treatments on the effect of leaf length (Table 1). Thus the highest leaf length $(14.36 \mathrm{~cm})$ was obtained from plot covered by black plastic whereas the lowest $(8.91 \mathrm{~cm})$ was obtained from control treatment. This might be due the effect of black plastic on soil moisture conservation which ultimately increase nutrient uptake of plant (Kwambe et al., 2015). This result has conformity with the finding of Castillo and Bacayan (2015) who reported that 
growing of lettuce under mulching resulted in the highest leaf length than control treatment.

\section{Leaf width}

The leaf width of lettuce was significantly ( $\mathrm{P}<$ 0.01 ) influenced by tested treatments. Application of black plastic resulted in the highest leaf width $(17.29 \mathrm{~cm})$ whereas the lowest was obtained from control treatment $(11.23 \mathrm{~cm})$ (Table 1$)$. This might be due to the positive effect of plastic mulches on enhancing microbial activity in the soil (Brault et al., 2002). Similar results were obtained by Mutetwa and Mtaita (2014) who indicated that yield of vegetables can be increased through application of mulches.

\section{Leaf number}

The analysis of variance revealed that there was significant difference $(\mathrm{P}<0.05)$ among the effects of treatments on leaf number. The highest leaf number (17.62) was obtained from the black mulch whereas the lowest (14.97) was obtained from control treatment (Table 1). The microclimate condition improved by the plastic mulches might have provided a suitable condition for producing higher number of leaves in the plants (Rajablariani et al., 2012). The current result is in line with the finding of Tosic et al., (2014) who conclude that mulching had positive effect on leaf number of lettuce as compared to control treatment (no mulching).

\section{Plant height}

Plant height was significantly $(\mathrm{P}<0.01)$ influenced by the effect of treatments. Thus the highest plant height $(16.43 \mathrm{~cm})$ was recorded from black mulch while the shortest $(11.24 \mathrm{~cm})$ was obtained from control treatment (Table 1). The result had conformity with the findings of Yaghi et al. (2013) on cucumber and Ashrafuzzaman et al. (2011) on lettuce who reported that increased vegetative growth and plant height under the application of black plastic mulch, respectively. The faster growing stem of the lettuce grown on black mulch may be due to the effect of higher temperature around the growing point (Brault et al., 2002).

Table1: Effect of mulch on leaf length, leaf width, leaf number, plant height

\begin{tabular}{|l|c|c|c|c|}
\hline Mulching material & Leaf length $(\mathbf{c m})$ & Leaf width $\mathbf{( c m )}$ & Leaf number/plant & Plant height $(\mathbf{c m})$ \\
\hline White plastic & $9.56 \mathrm{bc}$ & $14.3125 \mathrm{~b}$ & $17.37 \mathrm{ab}$ & $13.3 \mathrm{~b}$ \\
\hline Black plastic & $14.36 \mathrm{a}$ & $17.295 \mathrm{a}$ & $17.62 \mathrm{a}$ & $16.43 \mathrm{a}$ \\
\hline Chickpea straw & $10.97 \mathrm{~b}$ & $12.45 \mathrm{c}$ & $15.73 \mathrm{cb}$ & $12.94 \mathrm{bc}$ \\
\hline Teff straw & $13.01 \mathrm{a}$ & $11.7975 \mathrm{c}$ & $15.9 \mathrm{abc}$ & $11.99 \mathrm{bc}$ \\
\hline Control (No mulch) & $8.91 \mathrm{c}$ & $11.235 \mathrm{c}$ & $14.97 \mathrm{c}$ & $11.24 \mathrm{c}$ \\
\hline LSD (5\%) & 1.53 & 1.47 & 1.82 & 1.93 \\
\hline CV (\%) & 8.77 & 7.13 & 7.25 & 9.49 \\
\hline
\end{tabular}

Means with in column sharing common letters are not significant different at $p<0.05$.

\section{Root volume}

The root volume of lettuce was significantly influenced by mulch type. Thus the highest $(4.76$ $\left.\mathrm{cm}^{3}\right)$ was obtained from black plastic $\left(2.59 \mathrm{~cm}^{3}\right)$ while the lowest was obtained from control treatment (Table 2). Mulches had significant positive effects on root elongation. This might be due to the conservation of enough soil moisture, suitable soil temperature as well as suitable microclimate condition. This result coincides with that of Ashrafuzzaman et al. (2011) who reported that black polythene mulch stimulates root growth.

\section{Dry matter}

The analysis of variance showed that there was significant $(\mathrm{P}<0.01)$ difference among treatments. The maximum (4.59\%) dry matter was obtained from black plastic whereas the minimum $(1.65 \%)$ was obtained from control treatment (Table 2). This result is in line to the result of Maboko et al. (2017) who reported that plastic mulches had a good comparative effect on leaf dry mass of Swiss chard as compared to other type of organic mulches and bare-soil. The positive effect was probably due to the reduction of nutrients lost due to leaching (Moniruzzaman, 2006), reaction 
of soil heat (Ghosh et al., 2006), and moisture conservation by mulching (Moniruzzaman, 2006, Chakraborty et al., 2008). Similarly organic mulches had nutrient recycling system for green waste in cities (Merfield, 2002).

\section{Marketable yield}

The analysis of variance indicated that there was significant difference among treatments on the effect of marketable yield. Thus the highest marketable yield (33.34 ton/ha) was obtained from black mulch while the lowest (18.53 ton/ha) was obtained from control treatment (Table 2). This might be because of black polyethylene mulch controlled all types of weeds in addition to soil moisture conservation (Davari, 2016). Similarly, Yaghi et al. (2013) reported that plastic mulch raised soil temperature of the planting field which promote faster crop development and earlier yield.

Table 2: Effect of mulch on root volume, dry matter content and marketable yield of lettuce

\begin{tabular}{|l|c|c|c|}
\hline $\begin{array}{c}\text { Treatments (Mulching } \\
\text { materials) }\end{array}$ & $\begin{array}{c}\text { Root volume } \\
\left(\mathbf{c m}^{\mathbf{3}}\right)\end{array}$ & $\begin{array}{c}\text { Dry matter content } \\
(\mathbf{\%})\end{array}$ & $\begin{array}{c}\text { Marketable yield } \\
\text { (ton/ha) }\end{array}$ \\
\hline White plastic & $4.28 \mathrm{a}$ & $3.37 \mathrm{~b}$ & $26.24 \mathrm{ab}$ \\
\hline Black plastic & $4.08 \mathrm{a}$ & $4.59 \mathrm{a}$ & $33.34 \mathrm{a}$ \\
\hline Chickpea straw & $4.85 \mathrm{a}$ & $4.59 \mathrm{bc}$ & $23.50 \mathrm{ab}$ \\
\hline Teff straw & $4.76 \mathrm{a}$ & $1.82 \mathrm{~cd}$ & $20.32 \mathrm{~b}$ \\
\hline Control (No mulch) & $2.59 \mathrm{~b}$ & $1.65 \mathrm{~d}$ & $18.53 \mathrm{~b}$ \\
\hline LSD $(5 \%)$ & 1.13 & 0.95 & 10.43 \\
\hline CV $(\%)$ & 17.83 & 21.71 & 30.84 \\
\hline
\end{tabular}

Means with in column sharing common letters are not significant different at $p<0.05$.

\section{Conclusion and Recommendation}

The use of black plastic mulch resulted in the highest leaf length, leaf width, plant height, leaf number, root volume, dry matter content and marketable yield of lettuce whereas the lowest was obtained from control treatment (no mulching).

Generally application of black plastic mulch gave highest yield of lettuce than other mulches. This indicated that black plastic mulch has great impact on yield of lettuce and this result may be due to increment of soil temperature and soil moisture which ultimately resulted in high yield of lettuce crop. Therefore, lettuce growers should be advised to utilize black plastic mulch to maximize lettuce productivity.

\section{Reference}

[1] Ashrafuzzaman, M.M, M.A Halim, M.R Ismail, S.M. Shahidullah and M.A. Hossain. 2011. Effect of Plastic Mulch on Growth and Yield of Chilli (Capsicum annuum L.). Brazilian Archives of Biology and Technology. 54(2): 321-330.
[2] Bosland, P.W. and E.J. Votava. 2000. Pepper: Vegetable and Spice Capsicum. CAB International, UK., ISBN13:9780851993355, Pp 204.

[3] Brault, D., S. Jenni, and K.A. Stewart. 2002. Effect of paper and plastic mulches on yield of iceberg lettuce (Lactuca sativa L.), weed control and bulk density in organic soil. Horticultural Research and Development Centre, Agriculture and Agri-Food Canada. http://docplayer.net/51593566.

[4] Castillo, H.B., and J.J.O. Bacayan. 2015. Evaluation of Organic Mulching Materials on Selected Highland vegetables. BPIBNCRDPSC, Guisad, Baguilo City. http://bpi.da.gov.ph

[5] Chakraborty, D., S. Nagarajan, P. Aggarwal, V.K. Gupta, R.K. Tomar, R.N. Garg, R.N. Sahoo, A. Sarkar, U.K. Chopra, K.S.S. Samara, and N. Kalra. 2008. Effect of mulching on soil and plant water status, and the growth and yield of wheat (Triticum aestivum L.) in semi-arid evvironment. Agriculture Water Management. 95: 1323-1334. 
[6] Davari, A. 2016. The role of mulching on soil characteristics. Int. J. Agri Biosci, 5(5): 250-256.

[7] FAO. 2009. Production Year Book. Food and Agriculture Organization of the United Nations. Rome, Italy.

[8] Geleta, L. 1998. Genetic variability and association study for yield, quality and other traits of yield of hot pepper (Capsicum species). M.Sc Thesis, Hramaya University, Ethiopia.

[9] Ghosh, P.K., D. Dayal, K.K. Bandyopadhyay, and M. Mohanty. 2006. Evaluation of straw and polythene mulch for enhancing productivity of irrigated summar grond nut. Field Crops Research. 99: 76-88.

[10] Gomez, K.A. and Gomez, A.A. 1984. Statistical Procedure for Agricultural Research (2nd edn.). Int. Rice Res. Inst., A Willey Int. Sci., Pub., pp. 28-192.

[11] Gopalan, R. and S.C. Balaraman. 1966. Health Bulletin of Indian Council of Medical Research. Special Report Series No. 42. pp.12-16.

[12] Kwambe, X.M., M.T. Masarirambi, P.K. Wahome, T.O. Oseni. 2015. The effects of organic and inorganic mulches on growth and yield of green bean (Phaseolus vulgaris $L$.) in a semi-arid environment. Agri. and Bio. J. North America. 6(3): 8189.

[13] Lindquist, K. 1960. On the origin of cultivated lettuce. Hereditas. 46: 319-349.

[14] Maboko, M. M., C. P. Du Plooy, M. A. Sithole, and A. Mbave1. 2017. Swiss Chard (Beta vulgaris L.) Water Use Efficiency and Yield under Organic and Inorganic Mulch Application. J. Agr. Sci. Tech. 19: 1345-1354

[15] Merfield, C. 2002. Organic weed management: A practical guide. Pp. 1-30. Lincoln University, http://researcharchive.lincoln.ac.nz/bitstrea $\mathrm{m} / 10182 / 4902 / 1 /$ Merfield-organic-weed2002.pdf.
[16] Moniruzzaman, M. 2006. Effects of Plant Spacing and Mulching on Yield and Profitability of Lettuce (Lactuca sativa L.). J. Agric. Rural Dev. 4(1\&2): 107-111.

[17] Mutetwa, M. and T. Mtaita. 2014. Effect of different mulch colors on cucumber production, Department of Horticulture, Faculty of Agriculture and Natural Resources, Africa University J. Glob. Innov. Agric. Soc. Sci. 2(4): 178-184.

[18] Rajablariani, H.R., F. Hassankhan, R. Rafezi. 2012. Effect of Colored Plastic Mulches on Yield of Tomato and Weed Biomass. Int. J. of Enviro. Sci. and Development. 3(6): 590- 593.

[19] Rashid, M. M. 1999. Origin and distribution of lettuce. Rashid Publishing House, DOHS, Dhaka-1000, pp. 495.

[20] Squire, G.R., C.K Ong, J.L. Monteith. 1987. Crop growth in semi-arid environment. In: Proceedings of 7 th International Workshop, 7-11 April, 1986, International Crops Research Institute for Semi-Arid Tropics, Patancheru, Hyderabad, pp 219-231.

[21] Tosic I., Z. IIin, I. Maksimovic, S. Pavlovic. 2014. Effect of plant mulching and covering on the lettuce yield and nitrate content (Lactuca sativa L.). Afri. J. Agri. Res. 9(23):1774-1777.

[22] Yaghi, T., A. Arslan, F. Naoum. 2013. Cucumber (Cucumis sativus L.) water use efficiency (WUE) under plastic mulch and drip irrigation. J. Agri. Water Mgt. 128: 149-157. 